\title{
Health seeking behavior of the families of children with cataract attending an eye clinic in Rio de Janeiro, Brazil
}

\author{
Perfil de procura dos serviços de saúde pelas famílias de crianças com catarata assistidas \\ em uma clínica oftalmológica no Rio de Janeiro, Brasil
}

Claudia Leite ${ }^{1}$, Andrea Zin²

\begin{abstract}
Purpose: To determine the health-seeking behavior of the families of children presenting with congenital and developmental cataract attending "Instituto Brasileiro de Oftalmologia" (IBOL), Rio de Janeiro, Brazil.

Methods: Caregivers of consecutive eligible children were interviewed using a pretested questionnaire and medical records were reviewed to collect information about their health-seeking behavior and socioeconomic status in June and July of 2008. Results: Data from 70 children were gathered, from which 42 (60.0\%) had bilateral disease. Fifty-eight (82.9\%) cases were considered congenital and $12(17.1 \%)$ developmental. Presentation delay was observed in $33(47.1 \%)$ children. Having insurance (adjusted OR 0.17; 95\% Cl $0.04-0.82$ ) and being the only child (adjusted OR 0.16; $95 \%$ $\mathrm{Cl} 0.04$ - 0.69) decreased likelihood of late presentation.

Conclusions: Delayed detection and presentation for treatment of non-traumatic pediatric cataract are still significant problems in the state of Rio de Janeiro. Early recognition as well as prompt referral and appropriate treatment have to be improved, especially at the public sector.
\end{abstract}

Keywords: Cataract/congenital; Cataract/therapy; Child; Health services

\section{RESUMO}

Objetivo: Determinar o padrão da procura dos serviços de saúde pelas famílias de crianças com catarata congênita e de desenvolvimento, assistidas no Instituto Brasileiro de Oftalmologia (IBOL), Rio de Janeiro, Brasil.

Métodos: Os responsáveis das crianças foram entrevistados utilizando um questionário pré-testado e seus prontuários foram revisados para obter informações sobre a procura dos serviços de saúde pelas famílias, assim como suas condições socioeconômicas, nos meses de junho e julho de 2008.

Resultados: Dados de 70 crianças foram obtidos, das quais 42 (60\%) tinham doença bilateral. Cinquenta e oito (82,9\%) casos foram considerados congênitos e 12 (17,1\%) de desenvolvimento. Atraso na apresentaçäo foi observado em $33(47,1 \%)$ crianças. O fato de a criança possuir seguro-saúde (OR ajustado 0,17; 95\% IC 0,04 - 0,82) e ser filho único ( OR ajustado 0,16; 95\% IC 0,04 - 0,69) reduziu a probabilidade de apresentação tardia. Conclusões: A detecção e apresentação tardia para tratamento da catarata pediátrica não-traumática são problemas ainda significantes no estado do Rio de Janeiro. O reconhecimento precoce assim como o encaminhamento imediato e tratamento apropriado tem que ser melhorados, principalmente no serviço público de saúde.

Descritores: Catarata/congênito; Catarata/terapia; Criança; Serviços de saúde

\section{INTRODUCTION}

The control of blindness in children is a priority of the International Agency for the Prevention of Blindness/World Health Organizations' (WHO) global initiative, VISION 2020 - the Right to Sight ${ }^{(1)}$ However, control strategies need to vary, as the magnitude and causes of visual loss in children vary significantly from country to country with a far higher proportion of causes being potentially avoidable in poor countries compared with affluent countries. Indeed, under-five mortality rates and infant mortality rates, which reflect levels of socioeconomic development and access to health care, can be used as proxy indicators for the prevalence and causes of blindness in children ${ }^{(1,2)}$. It is estimated that bilateral cataract is responsible for $15 \%$ of all childhood blindness in the world, with an incidence of at least 10 new cases per million people per year ${ }^{(3)}$.

In Latin American countries, retinal diseases are the major causes of visual impairment and blindness in children ${ }^{(4-8)}$. Nevertheless, cataract still accounts for $6.4 \%$ to $12.7 \%$ of visual loss among children attending low vision services in Brazil and Chile $e^{(4,6-8)}$.
Surgical intervention is indicated in the majority of total cataract in children. Prompt surgery is even more important in dense congenital cataracts and early developmental cataracts $(9,10)$. For total unilateral congenital cataract, surgery is indicated by 6 to 8 weeks of life to minimize amblyopia ${ }^{(11-13)}$. Regarding bilateral cases, optimal timing of surgery has to be established since early surgery is associated with higher incidence of aphakic glaucoma but surgery before three months of life is desirable $(9,11,14)$.

Early identification of cataract and prompt referral for specialized treatment are needed for good visual results. Despite existence of the simple and non-invasive red reflex test for cataract detection ${ }^{(11,15-18)}$, screening is not a common practice in the majority of countries and most of the time delay detection is made by parents when they notice leukocoria, nystagmus or/and strabismus $(9,10,19,20)$.

In Brazil, surgery for cataract in children is performed in both private and public tertiary centers, although ophthalmic services differ in terms of availability and quality in these two sectors. Also, socioeconomic development and many health aspects vary from one region to the others of the country ${ }^{(21)}$.
Submitted for publication: July 4, 2010

Accepted for publication: August 4, 2011

Study was carried out at the Pediatric Ophthalmology Sector, Instituto Brasileiro de Oftalmolologia IBOL - Rio de Janeiro (RJ), Brazil.

Physician, Pediatric Ophthalmology Sector, Instituto Brasileiro de Oftalmolologia - IBOL - Rio de Janeiro (RJ), Brazil.

Physician, Neonatology Department, Unidade de Pesquisa Clínica, Instituto Fernandes Figueira Rio de Janeiro (RJ), Brazil.
Funding: No specific financial support was available for this study

Disclosure of potential conflicts of interest: C.Leite, None; A.Zin, None.

Correspondence address: Claudia Leite. Instituto Brasileiro de Oftalmologia- Praia de Botafogo, 206 - Rio de Janeiro - RJ - 22250-040 - Brazil - E-mail: claudoctor@hotmail.com

Editorial Note: After completing the confidential analysis of the manuscript, ABO discloses, with their agreement, the names of Dr. Mônica Fialho Cronemberger and José Augusto Alves Ottaiano as revieweres. We thank your effort and expertise in participating in this process. 
"Instituto Brasileiro de Oftalmologia "(IBOL) is a private clinic in Rio de Janeiro and a referral center for eye diseases in Rio de Janeiro state. A local non-governmental organization (NGO), named "Instituto Catarata Infantil" (ICl) was established in 2004 to support children from low income families who do not have insurance but need cataract surgery. The NGO supports cataract surgery at IBOL at a reduced cost and all examinations and surgery are done by the same professionals, using the same infrastructure and equipment, as private patients.

It was sought to describe the health-seeking behavior of families of children presenting with congenital or developmental cataract attending IBOL in Rio de Janeiro, by direct appointment or by $\mathrm{ICl}$, and investigate factors associated with delay in diagnosis and/ or presentation for treatment.

\section{METHODS}

This cross-sectional study was conducted in June and July 2008, in the pediatric ophthalmic sector of "Instituto Brasileiro de Oftalmologia" (IBOL) with its private patients and those assisted by "Instituto Catarata Infantil" (ICI).

The study population consisted of children aged less than 16 years with unilateral or bilateral cataract who had attended the ICI and IBOL since 1999. New cases and follow-up cases of congenital and developmental cataract were enrolled on the study. Traumatic cases were excluded. The study was explained and an information sheet was read and informed consent obtained from caregivers.

An interview with children's guardians was conducted, using a pre-tested questionnaire. Interviews were conducted either faceto-face or by telephone. Parents were contacted by telephone if their children did not have an appointment scheduled and/or lived far from the hospital. The following data were collected: demographic details, health-seeking behavior, and socio-economic status. The health-seeking behavior sector of the questionnaire included a series of questions related to the steps from the time a problem was first noticed to the first visit to hospital where treatment was started. Additionally, participants' medical records were reviewed to assess information about etiological, perinatal and prenatal factors as well as details of the disease and other associated anomalies.

Economic status of children's families was classified in five major categories ( $A, B, C, D$ and $E$ ) using the new Brazilian Economic Classification of the Brazilian Association of Research Companies ${ }^{(22)}$. Additionally, household income grouped according to the national minimal salary (MS) and parent's educational level was assessed. The value of Brazilian MS was 415 reais or 259.4 dollars during the study. Concerning their level of education, parents were grouped in 3 categories: 1. Low education, when they did not have any formal education or studied up to the last year of primary education; 2. Medium, if they had completed part or total of secondary school; 3. High, if they had studied further than secondary school.

Those children whose cataracts were noticed when the child was below one year of age were classified as having congenital cataract and those who developed cataract after one year of age were classified as having developmental cataract.

Detection of the cataract was the moment a problem on the child was first noticed by someone. Presentation time to a health worker was defined as the period of time between cataract detection and the first visit to a health worker, and presentation time to treatment as the period between the latter and being seen by specialized ophthalmologist who started treatment. Delayed presentation time to a health worker was considered if caregivers took more than one month to seek for first help. Moreover, delay in presenting to treatment was considered if this period was more than two months. Finally, total presentation time, the time taken from detection to presentation for treatment, was considered delayed when the treatment started four or more months after detection.
All questionnaires were checked at the end of each interview Epidata was used for data entry. Excel, SPSS and Stata software were used for analysis. Non-parametric tests (Mann- Whitney) were used to analyze skewed data. Chi-squared test measured the association between categorical variables. In addition, risks factors for delay in presentation were analyzed using univariate and multivariable analysis.

Ethical approval from the LSHTM Ethics Committee was obtained. Permission from $\mathrm{IBOL}$ and $\mathrm{ICI}$ to review medical records and interview children's guardians was also taken in advance.

\section{RESULTS}

Data from 70 children were gathered, 38 (54.3\%) of whom were boys. The median child's age at the time of interview was 46.5 months (range 1- 124 months; lower quartile (LQ) - 28; upper quartile (UQ) 81). Thirty-three $(47.1 \%)$ interviews were conducted by telephone and the other 37 (52.9\%) were conducted face-to-face.

The mean age of mothers at the birth of their affected child was 27.8 years (range 14 to 40 years; SD 6.7). Sixty-four (91.4\%) children were follow-up cases and only six (8.6\%) were new cases; 28 (40\%) children had unilateral cataract and 42 (60\%) had bilateral cataract. Fifty-eight $(82.9 \%)$ cases were considered congenital and 12 (17.1\%) developmental (Table 1). Surgery was indicated for 65 patients (92.9\%).

Mothers $(44,62.9 \%)$ or another relative $(9,12.9 \%)$ were usually the first person to recognize that the child had an eye condition. In 44 children (62.9\%), a "white pupil" (i.e. leukocoria) was the first abnormality detected followed by difficulty in seeing in 11 (15.7\%), strabismus in 5 (7.1\%), nystagmus in 4 (5.7\%), and 6 (8.6\%) children had other signs. Health workers detected the abnormality in 17 children (24.3\%): 10 (14.2\%) pediatricians, 6 (8.6\%) ophthalmologists and one nurse (1.4\%). The median age at detection was 2 months (range 1-73, LQ - 1; UQ - 8) (Table 1). There was no significant difference between unilateral and bilateral cases.

In those 58 congenital cases, 42 (72.4\%) had the problem noticed by the age of 3 months, mostly by parents or relatives (Table 2).

In fifty percent of cases an ophthalmologist was the first health professional parents visited for help. Additionally, the other half (35) of parents relied on pediatricians to make the diagnosis. Presentation time to a health worker varied from less than one week to 69 weeks, median time 2 weeks (LQ - 1; UQ - 4). In only 13 (18.6\%) cases caregivers took more than month, the main causes reported were: $6(8.6 \%)$ parents did not know who to look for/where to go, in 3 (4.3\%) they thought that was normal of age or not serious, in 2 (2. 9\%) cases child had more important problems to treat first and 2 (2. 9\%) people related other causes.

Presentation time to treatment varied from zero to 169 weeks, median time 8 weeks (LQ - 2; UQ - 35). In thirty-one (44.3\%) children presentation time to treatment was longer than 2 months. There was a significant difference between the first professional sought for help and delay in presentation to treatment (Table 3). The main causes were: 10 (14.3\%) parents did not know who to look for/where to go, $7(10 \%)$ waited for treatment in a public hospital, $6(8.6 \%)$ had difficulties in making an appointment, in 5 (7.1\%) pediatricians neither diagnosed the cataract nor referred them and $3(4.3 \%)$ people reported other causes.

The median child's age when treatment was started was 8 (range 1 - 74) months, (LQ - 3; UQ - 24). In the group of children with congenital cataract, the median child's age was 6.5 (range 1 - 48) months, (LQ 2; UQ - 30). In the other group with developmental cataract it varied from 26 to 74 months, median age 47.5 (LQ - 32; UQ - 57).

Total presentation time varied from less than 1 month to 40 months, median time 3 (LQ - 1; UQ - 10). Thirty-three (47.1\%) patients had total presentation delay: $3(4.3 \%)$ at the presentation to health worker, $24(34.3 \%)$ in presentation to treatment and 6 
Questionnarie. Cataract in children: health seeking behaviour and cost of treatment

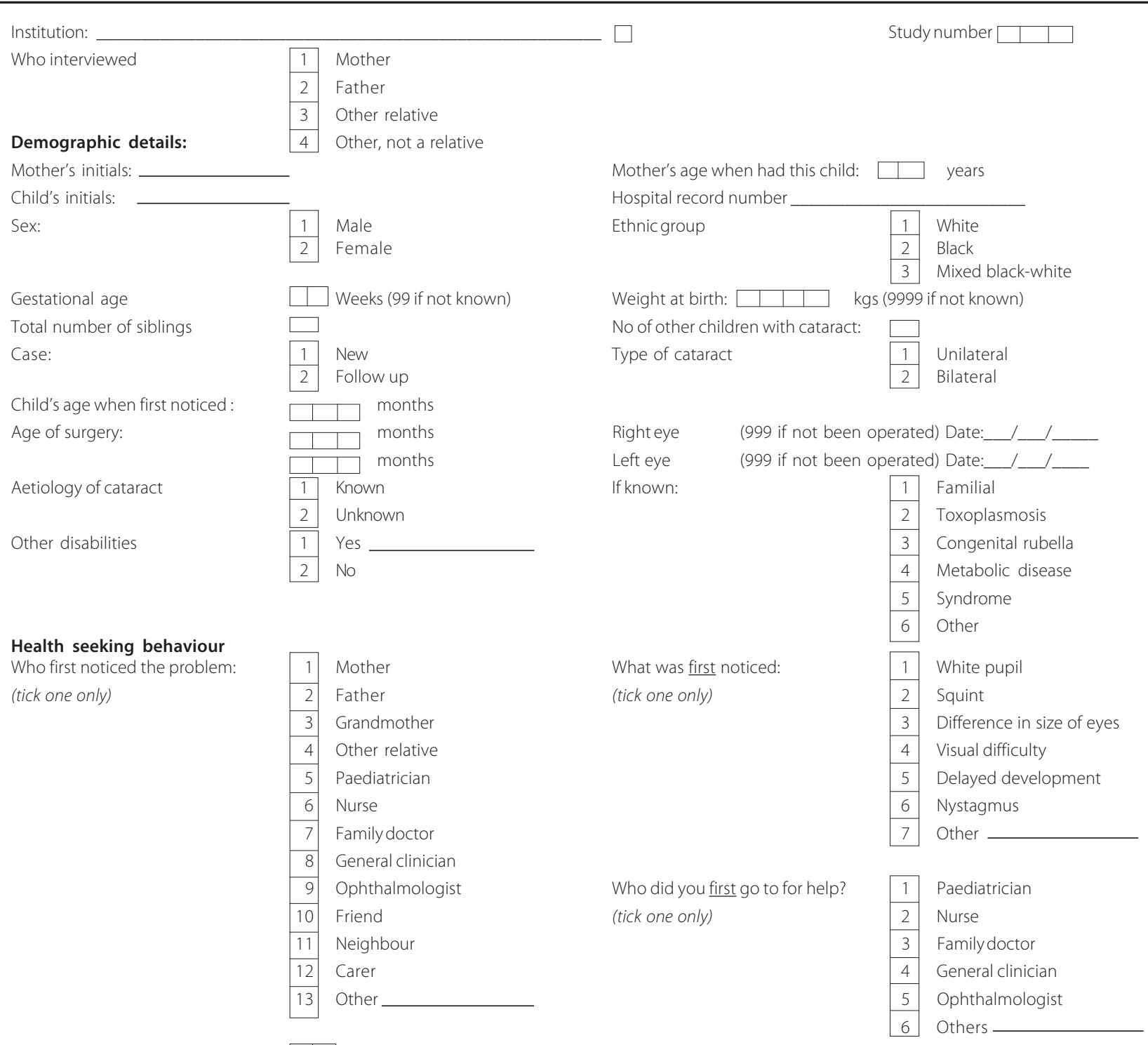

How long did you take to look for help?

weeks

If more than 1 month, what was the main reason of delay?

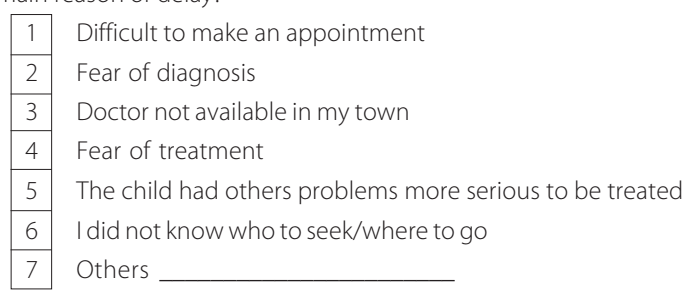

How many ophthalmologists/services did you visit before coming to this service?

After been referred, how long did it take to be seen by the specialized ophthalmologist in this service? $\square \quad \square$ weeks

If more than 2 months, what was the main reason of delay?

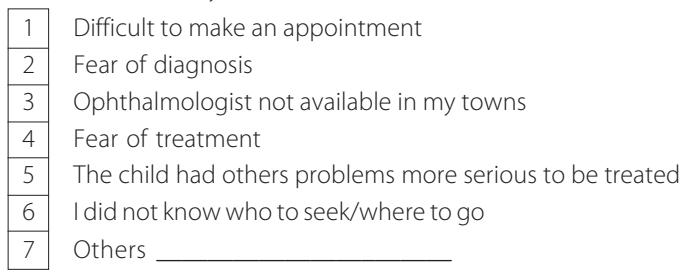


(Continuation questionnaire) Cataract in children: health seeking behaviour and cost of treatment

How old was the child when treatment recommended by ophthalmologist started? $\square \quad \square \quad \square$ months

Socioeconomic Status

Marital status of mother

Occupation

To be used by researcher

\begin{tabular}{|c|c|c|}
\hline \multirow[b]{2}{*}{ Transport owned by household } & \multicolumn{2}{|c|}{ Mother } \\
\hline & 0 & None \\
\hline & 1 & Pedal b \\
\hline & 2 & Motorb \\
\hline & 3 & Car \\
\hline & 4 & Lorry \\
\hline & 1 & Up to 4 \\
\hline Household income per month & 2 & $415-1$ \\
\hline & 3 & $1,246-$ \\
\hline & 4 & $2,491-$ \\
\hline & 5 & $4,151-$ \\
\hline & 6 & more th \\
\hline No of bedrooms: $\square \square$ & & \\
\hline People living in the household: & \begin{tabular}{|l|l|} 
& \\
\end{tabular} & Adults \\
\hline No of color TV & $\square$ & \\
\hline Do you have VCR or DVD? & $\square$ & Yes \\
\hline & $\square$ & No \\
\hline Do you have refrigerator? & $\square$ & Yes \\
\hline fomplounec(calarinc) & $\square$ & No \\
\hline
\end{tabular}

Actual out of pocket costs of treatment for the family

\section{Travel costs:}

No of adults usually accompanying child

Number of visits (outpatient + surgery):

Usual method of transport to eye clinic:

\begin{tabular}{|c|c|}
\hline 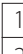 & Walked \\
\hline 2 & Ambulance \\
\hline 3 & Bus \\
\hline 4 & Train \\
\hline 5 & Motorbike \\
\hline 6 & Taxi \\
\hline 7 & Own car \\
\hline 8 & Friend/relative's ca \\
\hline & Plane \\
\hline
\end{tabular}

Travel costs for one visit:

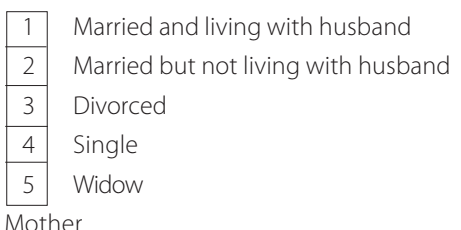

\begin{tabular}{|c|l}
\hline 0 & No formal education \\
\cline { 1 - 1 } 1 & Primary only \\
\cline { 1 - 1 } 2 & Incomplete secondary \\
\cline { 1 - 1 } 3 & Secondary \\
\cline { 1 - 1 } 4 & Incomplete tertiary \\
\cline { 1 - 1 } 5 & Complete tertiary \\
\cline { 1 - 1 } 6 & Post graduate
\end{tabular}

Father

\begin{tabular}{|l|l}
\hline 0 & No formal education \\
\cline { 1 - 1 } 1 & Primary only \\
\cline { 1 - 1 } 2 & Incomplete secondary \\
\cline { 1 - 1 } 3 & Secondary \\
\cline { 1 - 1 } 4 & Incomplete tertiary \\
\cline { 1 - 1 } 5 & Complete tertiary \\
\cline { 1 - 1 } 6 & Post graduate \\
\hline
\end{tabular}

Father
Mother
Father $\quad \begin{aligned} & \text { Number } \\ & \text { Number }\end{aligned}$

Motorbike

to 415 reais

, 4,150 reais

4,151 - 8,300 reais

ore than 8,300 reais

Housing

Father
\begin{tabular}{|l|l}
\hline 0 & None \\
\cline { 1 - 1 } 1 & $\begin{array}{l}\text { Pedal bike } \\
\text { Pn }\end{array}$ \\
\cline { 1 - 1 } 3 & $\begin{array}{l}\text { Motorbike } \\
\text { Car }\end{array}$ \\
\cline { 1 - 1 } 4 & Lorry
\end{tabular}

\begin{tabular}{|c|c|}
\hline 1 & Rented house/flat \\
\hline 2 & Own house/flat \\
\hline & Public dormitory \\
\hline 2 & Other \\
\hline
\end{tabular}

No of bathrooms



Child Bus \begin{tabular}{l|l|l|}
\hline & & \\
\hline
\end{tabular}

Train $\square=1 \quad$ Rs

Taxi

Plane \begin{tabular}{l|l|l|l|}
\hline & & & \\
\hline
\end{tabular}
Adult 1
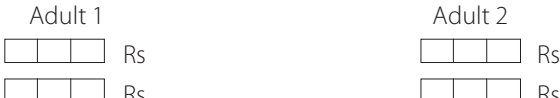

Total

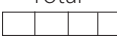

\begin{tabular}{|l|l|l|l|}
\hline & & & \\
\hline
\end{tabular}

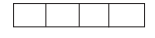


Friend/relative's car

Motorbike

Own car

Costs with food (each visit) Total cost

Accommodation costs for visits:

Number of nights had overnight stay

Cost of overnight stay

Total cost of overnight stays:

Consultation and surgery:

Insurance for consultation:

Consultation fee paid by family:

Total consultation fee(s) paid:

Examination under sedation

Hospital charges paid by family:

Physicians' payment:

Total per examination

Surgical fee paid by family:

Ophthalmologists' payment

Total paid for ophthalmologists:

Hospital charges paid by family:

Total hospital charges paid:

Anesthesiologist's payment:

Total paid for anesthesiologists:

Intraocular lenses

Opportunity costs

Lost of income for adults:

Other costs:

\section{Other costs}

Glasses:

Contact Lenses

Eye patches

Low vision devices

Medication

Other costs


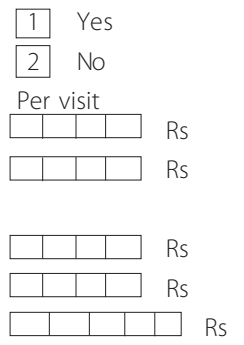

First operation
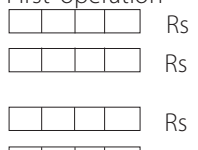

\begin{tabular}{|l|l|l|l|}
\hline & & & \\
\hline
\end{tabular}
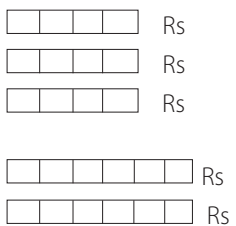

\section{Rs}

Rs
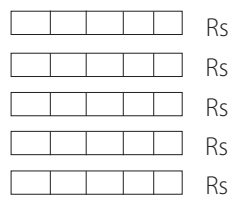

Grand total for all visits:

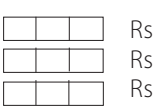

Rs
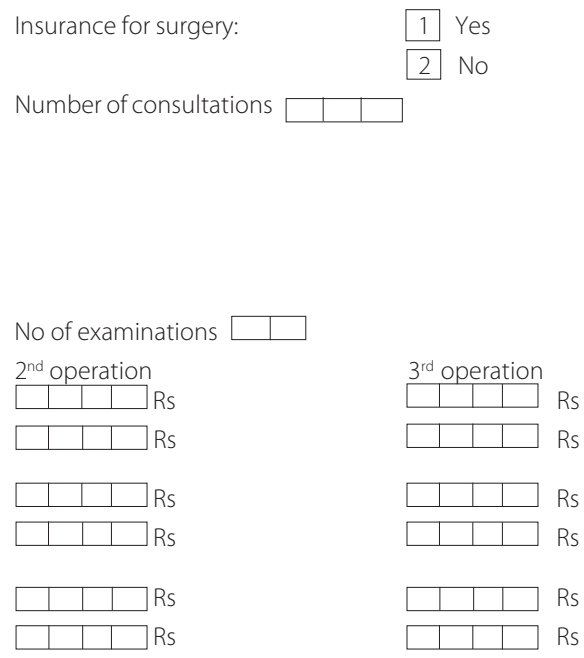

Specify

Total spent on glasses $(000=$ none $)$

Total spent on contact lenses $(000=$ none $)$

Total spent on eye patches $(000=$ none $)$

Total spent on low vision devices ( $000=$ none)

Total spent on medication $(000=$ none $)$

Specify:
(8.6\%) in both periods. Initially, total delay of treatment was associated with mother's educational level ( $p=0.008)$, father's educational level $(p=0.018)$, household income $(p=0.002)$, being the only child $(p=0.001)$ and having insurance $(p<0.001)$. Using a multiple logistic regression modeling, only the last two factors showed a protective effect after controlling for the other variables. Children without siblings were $84 \%$ less likely to have a delay in their treatment compared to those with siblings. Moreover, children whose families had insurance were $83 \%$ less likely to have their treatment delayed compared to those without insurance (Table 4).

There is no statistically significant difference in total presentation time between children with congenital or developmental cataract (Mann-Whitney $U=253.50 ; p=0.14$ ).

\section{DISCUSSION}

Cataract remains an important cause of blindness in children as many studies around the world have shown ${ }^{(4-8)}$. Prevention is limited since many aspects of its etiopathogenesis are still unknown. Consequently, early diagnosis and prompt referral for proper treatment are even more important in increasing the probability of these children developing sight.

In the great majority, cataract was suspected by mothers (62.9\%); with leukocoria being the main sign which demonstrates how easily detectable is the disease, particularly in more advanced cases. Despite the existence of a law which obliges examination of red reflex of neonates by pediatricians in all maternity units of the state of Rio de Janeiro since the year of 2002, in this study only 7 (12.1\%) of the 58 children with congenital cases had their cataract identified by a pediatrician by 3 months of age. This might be a reflex of lack of pediatricians' training in recognizing eye problems. In total, only about $25 \%$ of the children (17) had their cataract detected by a health worker. An evaluation of the existent screening program in the United Kingdom showed that $47 \%$ of their congenital cataracts had been detected through routine examination by the age of 3 months ${ }^{(18)}$. 
In Brazil, although primary health care is well established and easily accessible, primary eye care is not normally incorporated to it.

Total delay in presentation in our study occurred mostly in seeking the specialized ophthalmologist who started treatment after the child had been seen by another health worker. Considering that half of caregivers sought directly an ophthalmologist as first health worker, a much lower proportion of delay on the second phase should be expected. Instead 11 (31.4\%) out of these 35 children had delay at treatment presentation, mostly due to problems in referral or treatment in the public health system. Additionally, other 20 children firstly seen by pediatricians had delay at treatment presentation, half of them (10) by referral problems due to lack of knowledge of specialized centers or difficulty in making appointment mainly in the public health system and also, although much less frequently, in the private sector. Moreover, in other 5 of these 20 cases lack of pediatricians' skills in diagnosing the problem was responsible for the delay.

Applying the same criteria used in this study for educational level to the population of the state of Rio de Janeiro about $17.0 \%$ were classified as having low education, 50.0\% medium education and $33 \%$ high education ${ }^{(21)}$. In the present study, similar figures were found for the parents' educational level, respectively: $16.4 \%$, $57.1 \%$ and $26.4 \%$. This may suggest our sample is representative of the population of the state of Rio de Janeiro. However, the mother's educational level in this setting was not a determinant in late presentation in this study. This finding contrasts with that of a similar study in Tanzania ${ }^{(23)}$. Furthermore, the gender of the child was not deter- minant in seeking for treatment as it is in some African and Asian settings s2-25) $^{(23)}$

In fact, the only two factors which showed significant negative relation to total late presentation were: having insurance and being the only child. The former was expected by some of the reasons mentioned above as a great number of children whose treatment was supported by NGO had already been seen or even treated in the public system before seeking or been referred to $\mathrm{ICl}$. Comparison of this result is not possible due to lack of similar studies. Furthermore, being the only child as a protective factor against delay in presentation could suggest higher level of parents' attention on their only child. In contrast, Mwende et al. ${ }^{(23)}$ found that children with congenital cataract who had siblings were 4.40 (95\% Cl 1.38 to 14.39 ) less likely to have a late presentation to hospital (after 12 months in their study) compared to only children in Tanzania.

The fact that the study was performed in a specialized hospital could introduce some bias since parents who attend these hospitals tend to be more health concerned or conscious, more likely to have higher socioeconomic status. Moreover, even with the NGO covering most of the costs, expenditure with transportation could deter some families from looking for help. Also, some level of inaccuracy in recalling details of their health-seeking behavior could occur particularly in cases of longer follow-up.

We considered the number of siblings at the day of interview which could not be same of that at the birth of the child. Therefore, association between this variable and total delay in presentation could be underestimated or overestimated.

Table 1. Median age of child at detection by type of cataract and laterality

\begin{tabular}{|c|c|c|c|c|c|}
\hline & \multicolumn{5}{|c|}{ Age of the child at detection (months) } \\
\hline & Median & Range & Lower quartile & Upper quartile & Frequency \\
\hline \multicolumn{6}{|l|}{ Type of cataract * } \\
\hline Congenital & 1 & $1-36$ & 1.0 & 4.0 & 58 \\
\hline Developmental & 30 & $18-73$ & 21.5 & 51.0 & 12 \\
\hline \multicolumn{6}{|l|}{ Laterality** } \\
\hline Bilateral & 2 & $1-55$ & 1.0 & 9.0 & 42 \\
\hline Unilateral & 1 & $1-73$ & 1.0 & 4.5 & 12 \\
\hline Total & 2 & $1-73$ & 1.0 & 8.0 & 70 \\
\hline
\end{tabular}

*Mann-Whitney test $=7.5 ; p<0.0001 ; * *$ Mann- Whitney test $=512.0 ; p=0.34$

Table 2. Age of child at detection by who detected her congenital cataract

\begin{tabular}{|c|c|c|c|}
\hline \multirow[b]{2}{*}{ Who detected } & \multicolumn{3}{|c|}{ Age of the child at detection (months) } \\
\hline & $\leq 3$ months (\%) & $>3$ months (\%) & Total \\
\hline Parents/relatives & $31(73.8)$ & $13(81.3)$ & $44(75.9)$ \\
\hline Pediatrician & $7(16.7)$ & $2(12.5)$ & $9(15.5)$ \\
\hline Other health worker & $4(9.5)$ & $1(6.2)$ & $5(8.6)$ \\
\hline Total & $42(100.0)$ & $16(100.0)$ & $58(100.0)$ \\
\hline
\end{tabular}

Pearson $\chi^{2}=0.3582 ; p=0.836$

Table 3. Delay in presentation to treatment by first professional sought for help

\begin{tabular}{|c|c|c|c|}
\hline \multirow[b]{2}{*}{ Delay } & \multicolumn{3}{|c|}{ Professional } \\
\hline & Ophthalmologist (\%) & Pediatrician (\%) & Total (\%) \\
\hline Yes & $11(31.4)$ & $20(57.1)$ & $31(44.3)$ \\
\hline No & $24(68.6)$ & $15(42.9)$ & $39(55.7)$ \\
\hline Total & $35(100.0)$ & $35(100.0)$ & $70(100.0)$ \\
\hline
\end{tabular}

Pearson $\chi^{2}=4.6898 ; p=0.03$ 
Table 4. Characteristics associated with total delay

\begin{tabular}{|c|c|c|c|c|}
\hline & \multicolumn{3}{|c|}{ Total presentation time } & \multirow[b]{2}{*}{$\begin{array}{c}\text { Adjusted OR }(95 \% \mathrm{Cl}) \\
\text { p value }\end{array}$} \\
\hline & $\begin{array}{r}\leq 3 \text { months } \\
n=37(\%)\end{array}$ & $\begin{array}{l}>3 \text { months } \\
n=33(\%)\end{array}$ & $\begin{array}{l}\text { OR }(95 \% \mathrm{Cl}) \\
\text { p value }\end{array}$ & \\
\hline \multicolumn{5}{|l|}{ Gender of child } \\
\hline Male & $24(63.2)$ & $14(36.8)$ & $2.50(0.95-6.58)$ & \\
\hline Female & $13(40.6)$ & $19(59.4)$ & $p=0.06$ & \\
\hline \multicolumn{5}{|l|}{ Mother's age at child's birth } \\
\hline$<30$ years & $20(51.3)$ & $19(48.7)$ & $0.87(0.34-2.23)$ & \\
\hline$\geq 30$ years & $17(54.8)$ & $14(45.2)$ & $p=0.77$ & \\
\hline \multicolumn{5}{|l|}{ Laterality of cataract } \\
\hline Bilateral & $21(50.0)$ & $21(50.0)$ & $0.75(0.29-1.96)$ & \\
\hline Unilateral & $16(57,1)$ & $12(42.9)$ & $p=0.56$ & \\
\hline \multicolumn{5}{|l|}{ Family history } \\
\hline Negative & $30(51.7)$ & $28(48.3)$ & $0.77(0.22-2.69)$ & \\
\hline Positive & $7(58.3)$ & $5(41.7)$ & $p=0.68$ & \\
\hline \multicolumn{5}{|l|}{ Number of siblings } \\
\hline One or more siblings & $18(39.1)$ & $28(60.9)$ & $0.17(0.05-0.53)$ & $0.16(0.04-0.69)$ \\
\hline Only child & $19(79.2)$ & $5(20.8)$ & $p=0.001$ & $p=0.014$ \\
\hline \multicolumn{5}{|c|}{ Marital status of parents (at recognition) } \\
\hline Married & $33(56.9)$ & $25(43.1)$ & $2.64(0.71-9.76)$ & \\
\hline Other & $4(33.3)$ & $8(66.7)$ & $p=0.15$ & \\
\hline \multicolumn{5}{|l|}{ Who first noticed the problem } \\
\hline Relatives & $26(49.1)$ & $27(50.9)$ & $0.53(0.17-1.63)$ & \\
\hline Health workers & $11(64.7)$ & $6(35.3)$ & $p=0.26$ & \\
\hline \multicolumn{5}{|l|}{ Mother's educational level } \\
\hline Low (primary/none) & $3(27.3)$ & $8(72.7)$ & $1.00 p=0.008 \chi^{2}$ trend $=6.95$ & 1.00 \\
\hline Medium (secondary) & $19(48.7)$ & $20(51.3)$ & $0.39(0.91-1.71)$ & $0.74(0.14-3.99) p=0.725$ \\
\hline High (tertiary) & $15(75.0)$ & $5(25.0)$ & $0.12(0.02-0.66)$ & $2.35(0.17-33.17) p=0.53$ \\
\hline \multicolumn{5}{|l|}{ Father's educational level } \\
\hline Low (primary/none) & $4(33.3)$ & $8(66.7)$ & $1.00 p=0.018 \chi^{2}$ trend $=5.58$ & 1.00 \\
\hline Medium (secondary) & $20(48.8)$ & $21(51.2)$ & $0.52(0.14-2.02)$ & $1.17(0.24-5.73) p=0.85$ \\
\hline High (tertiary) & $13(76.5)$ & $4(23.5)$ & $0.15(0.03-0.79)$ & $1.32(0.15-12.06) p=0.80$ \\
\hline \multicolumn{5}{|l|}{ Economic category } \\
\hline Class $\mathrm{A}+\mathrm{B}$ & $18(66.7)$ & $9(33.3)$ & $2.53(0.89-7.10)$ & \\
\hline Class C+D & $19(44.2)$ & $24(55.8)$ & $p=0.68$ & \\
\hline \multicolumn{5}{|l|}{ Household income } \\
\hline$\leq 3$ minimal salaries (MS) & $16(38.1)$ & $26(61.9)$ & $1.00 p=0.002 \chi^{2}$ trend $=9.82$ & 1.00 \\
\hline 4- $6 \mathrm{MS}$ & $10(66.7)$ & $5(33.3)$ & $0.31(0.09-1.06)$ & $0.74(0.14-3.83) p=0.72$ \\
\hline$>6 \mathrm{MS}$ & $11(84.6)$ & $2(15.4)$ & $0.11(0.02-0.57)$ & $0.17(0.01-2.79) p=0.21$ \\
\hline \multicolumn{5}{|l|}{ Insurance } \\
\hline No & $13(33.3)$ & $26(66.7)$ & $0.15(0.04-0.43)$ & $0.17(0.04-0.82)$ \\
\hline Yes & $24(77.4)$ & $7(22.6)$ & $p<0.001$ & $p=0.027$ \\
\hline
\end{tabular}

\section{ACKNOWLEDGMENTS}

The authors thank colleagues and staff of the eye clinic (IBOL) and "Instituto Catarata Infantil".

\section{REFERENCES}

1. Gilbert C, Foster A. Childhood blindness in the context of VISION 2020 - the right to sight Bull World Health Organ. 2001;79(3):227-32.

2. World Health Organization. Global initiative for the elimination of avoidable blindness. Geneva: World Health Organization; 1998.

3. Gilbert C. Childhood blindness. Foster A. In: A Manual for VISION 2020 Workshops. London: London School of Hygiene and Tropical Medicine; 2002. p. 29-44.

4. Gilbert C, Cánovas Emhart R, Kocksch Werner R, Foster A. Ceguera infantil en Chile: estudio de escuelas de ciegos. Arch Chil Oftalmol. 1993;50(2):49-53.

5. Zuluaga C, Sierra MV, Asprilla E. Causas de ceguera infantil en Cali, Colombia. Colomb Med. 2005;36(4):235-8.

6. Haddad MA, Sei M, Sampaio MW, Kara-José N. Causes of visual impairment in children: a study of 3,210 cases. J Pediatr Ophthalmol Strabismus. 2007;44(4):232-40.

7. Haddad MA, Lobato FJ, Sampaio MW, Kara-José N. Pediatric and adolescent population with visual impairment: study of 385 cases. Clinics (Sao Paulo). 2006;61(3):239-46.

8. Brito PR, Veitzman S. Causas de cegueira e baixa visäo em crianças. Arq Bras Oftalmol. 2000;63(1):49-54.

9. Roche O, Beby F, Orssaud C, Dupont Monod S, Dufier JL. [Congenital cataract: general review]. J Fr Ophthalmol. 2006;29(4):443-55. French.
10. Basti S, Greenwald MJ. Principles and paradigms of pediatric cataract management. Indian J Ophthalmol. 1995:43(4):159-76.

11. Rahi JS. Congenital and infantile cataract. In: Wormald R, Smeeth L, Henshaw K, editors. Evidence-based ophthalmology. London: Blackwell BMJ Books; 2003. p. 47-51.

12. Wilson ME Jr, Trivedi RH, Hoxie JP, Bartholomeu LR. Treatment outcomes of congenital monocular cataracts: the effects of surgical timing and patching compliance. J Pediatr Ophthalmol Strabismus. 2003;40(6):323-9; quiz 353-4. Comment in J Pediatr Ophthalmol Strabismus. 2003:40(6):322.

13. Birch EE, Stager D, Leffler J, Weakley D. Early treatment of congenital unilateral cataract minimizes unequal competition. Invest Ophthalmol Vis Sci. 1998;39(9):1560-6.

14. Arieta CEL, Kara José N. Catarata congênita: dificuldades no tratamento. Arq Bras Oftalmol. 1987;50(3):116-9.

15. Haargaard B, Wohlfahrt J, Fledelius HC, Rosenberg T, Melbye M. Incidence and cumulative risk of childhood cataract in a cohort of 2.6 million Danish children. Invest Ophthalmol Vis Sci. 2004;45(5):1316-20.

16. Rahi JS, Dezateux C. Congenital and infantile cataract in the United Kingdom: underlying or associated factors. British Congenital Cataract Interest Group. Invest Ophthalmol Vis Sci. 2000;41(8):2108-14.

17. Magnusson G, Persson U. Screening for congenital cataracts: a cost- consequence analysis of eye examination at maternity wards in comparison to well- baby clinics. Acta Paediatr. 2005;94(8):1089-95.

18. Rahi JS, Dezateux C. National cross sectional study of detection of congenital and infantile cataract in the United Kingdom: role of childhood screening and surveillance. The British Congenital Cataract Interest Group. BMJ. 1999;318(7180):362-5.

19. Mérula RV, Fernandes LC. Catarata infantil: importância do diagnóstico e tratamento precoces. Arq Bras Oftalmol. 2005;68(3):299-305. 
20. Oliveira MLS, Di Giovanni ME, Porfírio Neto Júnior F, Tartarella MB. Catarata congênita: aspectos diagnósticos, clínicos e cirúrgicos em pacientes submetidos a lensectomia. Arq Bras Oftalmol. 2004;67(6):921-6.

21. Instituto Brasileiro de Geografia e Estatística - IBGE. Censo brasileiro. [citado 2011 Set 9]. Disponível em: http://www.ibge.gov.br/home/

22. ABEP. Critério Padrão de Classificação Econômica Brasil/ 2008. [citado 2007, jun]. Disponível em: http://www.viverbem.fmb.unesp.br/docs/classificacaobrasil.pdf
23. Mwende J, Bronsard A, Mosha M, Bowman R, Geneau R, Courtright P. Delay in presentation to hospital for surgery for congenital and developmental cataract in Tanzania. Br J Ophthalmol. 2005;89(11):1478-82.

24. Eriksen JR, Bronsard A, Mosha M, Carmichael D, Hall A, Courtright P. Predictors of poor follow-up in children that had cataract surgery. Ophthalmic Epidemiol. 2006;13(4):237-43. 25. Muhit MA, Shah SP, Gilbert CE, Hartley SD, Foster A. The key informant method: a nove means of ascertaining blind children in Bangladesh. Br J Ophthalmol. 2007;91 (8):995-9

\section{Congresso Internacional de Catarata e Cirurgia Refrativa}

\section{0 de maio a 2 de junho de 2012}

Parque Anhembi - SP

\section{Informações:}

CENACON - Centro Nacional de Congressos

Tel: (17) 3214-5900 - Fax: (17) 3214-5905

Site: http://www.cataratarefrativa2012.com.br 